\title{
A question of confidence
}

\author{
An editor's view
}

STEPHEN LOCK

For the editor of the $B M \mathcal{F}$ to receive an official letter from the registrar of the General Medical Council must be unusual. So were the circumstances, which need a little space to describe.

By all accounts Gladwin Buttle was an outstanding man. Even among the fulsome tributes characteristic of the $B M F$ obituary columns he emerges as a true original, someone who left the world different from how he found it and who would have been a welcome dinner guest. His foremost contribution-the large scale development of blood transfusion in the second world war -was, it hardly needs to be said, made against all sorts of official opposition: he had to collect empty gin and whisky bottles from the officers' mess in Cairo, and have needles, rubber tubing and bungs, and glass drip chambers made locally; as a result the surgery of the battlefield was transformed from El Alamein onwards.

Nevertheless, the follow up obituary tribute was even more interesting:

We returned from dinner at the Turf Club to the fifteenth Scottish general hospital (his base) to be told that there was an unconscious man in the operating theatre. He had cut his throat in a hotel and had lost a lot of blood. Buttle said, "Give him some $O$ blood, while I find out who he is." After nearly three pints the patient was coming round and getting restless. Buttle returned and said, "Catch your train back to Alexandria; I will take over." I asked, "Who is he ?" $\mathrm{He}$ replied, "Orde Wingate." At breakfast next day there was discussion about how this already near legendary guerrilla fighter had been so depressed that he had cut his throat. A malariologist asked, "Have you looked at a blood film ?" It was swarming with malarial parasites. Wingate had cerebral malaria, not Atabrine poisoning as others have suggested. Buttle told me recently that he had several talks with

British Medical Journal, London WC1H 9JR

STEPHEN LOCK, MB, FRCP, editor
Wingate while he recuperated and he was eminently sane; and, of course, he was found fit some months later to command four divisions of Allied Chindits, when he was tragically flown into a mountain on the Burmese front.

In repeating this account I have "transgressed" again, contravening the guidelines on confidentiality published last autumn by the General Medical Council. At the end of September, two and a half months after this tribute was published, I received a letter from the registrar of the GMC. It appeared to the chairman of the Preliminary Proceedings Committee, the letter stated, that the obituary tribute had disclosed confidential information which the writer had obtained in the course of a professional relationship with the late General Wingate. The death of a patient did not absolve the doctor from the obligation to maintain secrecy, while the revised guidance which the GMC had adopted in May 1983 was that confidentiality applied equally to medical information received in the course of a doctor's administrative or non-clinical duties. Though the chairman did not propose to institute formal disciplinary proceedings against me, he invited my observations.

On reflection it became increasingly clear that an important principle was at stake; applied rigidly and unthinkingly such a clause was not in the best interests of society as a whole, and it could put at least two small groups of doctors (historians and journalists) at a disadvantage.

In the interests of brevity a $B M \mathcal{F}$ staff editor had deleted the obituary account of Wingate's illness and I had taken a deliberate decision to restore it. Wingate's image in history is of an erratic but brilliant commander, whose mental instability was typified by his suicide attempt, and he needed Churchill's support to regain command. To reverse this impression and put the blame fairly and squarely where it belonged-on cerebral malariawas important for "rehabilitating" Wingate's reputation, and this obituary tribute did just that. 
"The chairman accepts," the registrar of the GMC wrote in reply to my letter making these points, "that in the eyes of specialists in military or medical history, the information disclosed might have been regarded as of value in restoring the reputation of the late General Wingate in relation to one unfortunate episode." Even so, the letter continued, the chairman very much doubted whether such a departure from the rule was justified, and I was asked to ensure that future material that the $B M f$ published conformed more strictly with it.

Five days before this letter was written, however, the full GMC had debated this question, referring it to its standards committee. Its president, Sir John Walton, asked me for a public or private discussion document for the next meeting of the standards committee, accepting my proviso that I would have to mention Wingate again-for without a concrete example the issues are difficult to illuminate. In this article, therefore, I shall try to give some examples of the difficulty an editor faces and make a plea for a full debate on the general question and the intelligent handling of any code.

\section{Moran's Churchill}

In any debate of this type the discussion must start by centring on one occurrence: the publication of Lord Moran's Churchill: the Struggle for Survival. Appearing only a year after its subject's death, with its descriptions of the illness and decline of a great national figure, this book aroused stronger feelings in the national press about the ethical issues than it did in medical journals (though many of the letters in the newspapers came from doctors), and it may still be doubted whether the issues have been debated with the objectivity and rigour that they deserve.

To take the correspondence columns of The Times alone, one doctor asked that publication should be stopped, another that the GMC should issue a warning notice, and a third that action should be taken to restore the profession's good name; Churchill's son, Randolph, said that he asked no more for his father than that "he should be treated by his physician in the same way that the generality of the people in this country are treated by their local GPs."

Lord Moran countered by claiming that his book had been written with Sir Winston's knowledge and approval, a statement which Sir Herbert Seddon corroborated, also pointing out that the criticisms were being made of serialised extracts in the Sunday Times rather than of the whole book (and clearly Randolph Churchill had not read the latter when he wrote to The Times).

The comments in the medical press were much more muted. They seem remarkable today principally because for once the normal polarities of the radical Lancet and establishment $B M F$ were almost reversed. "Sir Winston may have agreed to the diaries appearing after his death," the Lancet commented in an editorial that was notable for lack of any argument, "but that is beside the point. The point is that Lord Moran, by writing publicly about the medical condition of an identified patient, is creating a modern precedent. It is a bad precedent which none should follow." The BMF's view, however, was that ethical laws were not immutable and evolved in response to the development of society, and it concluded rather tamely that most doctors would be unwilling to countenance any loosening of traditional professional reticence.

Possibly the small amount of comment on Moran's book in the medical press may have reflected that many doctors thought that the whole affair was sub judice: perhaps, they speculated, Lord Moran was due to appear before the GMC or the Central Ethical Committee of the BMA. Possibly, on the other hand, it testified to the respect that the profession had for an elderly man and a distinguished physician. As Lord Brain said in a letter to The Times: "I hope that this unhappy controversy will not be allowed to obscure Lord Moran's great service to Sir Winston. Over the years I saw his dedication at first hand and I know that it was given at great personal sacrifice."

Again many doctors may not have felt that any great harm had been done by Moran's disclosures. A final point of view, however, is that Moran was justified in writing as he did. Everybody had great admiration for Churchill's wartime leadership, but the medical incidents over this period were relatively few and far between-though they were emphasised in the serialised extracts of the book-and I doubt whether this section of the book would have suffered if they had been left out altogether. Churchill's decline after the war is a different matter: he was an obstinate old man, like some others of his age adrift in a world he did not understand but concerned to keep power for himself and to deny it to others. Moran shows us the tragic medical background to this period, which we have been reminded of recently with the release of the papers relating to the cover up about Churchill's stroke-a cover up from which even most of the Cabinet were excluded.

\section{Illness in our leaders}

In any case, in my personal view, society has a right to insist that it is not governed by those lacking full possession of their faculties.

"If for no other reason an inquiry into the health of those who carry responsibility for the livelihood, and indeed the lives, of others, far from being vulgar curiosity, is one of the most important and neglected factors in the defence of the realm, our freedom, and way of life. Illness cannot be a private matter for those who seek to become public figures."

Hugh L'Etang's Fit to Lead? makes this point in the context of a whole list of leaders whose terms of office were burdened with illness: Roosevelt (severe hypertension and debility); Eisenhower (myocardial infarction, stroke, and intestinal obstruction); Kennedy (back injury and Addison's disease); Eden (bile duct infection); Macmillan (acute retention and prostatic hypertrophy); Brezhnev (stroke and heart block); Pompidou (macroglobulinaemiol); Jinnah (advanced pulmonary tuberculosis); Nehru (prostatic hypertrophy and uraemia); and Nasser (diabetic neuropathy).

Nevertheless, L'Etang has never had to ask for information from doctors; details of illnesses, he tells me (personal communication 1983), are usually published by non-medical writers and almost invariably with the consent of relatives.

Such details given by laymen may be just as full as if they had been provided by a doctor:

"Graham was beginning to show the symptoms of an enlarged liver ... a local doctor ... . made arrangements for him to see the leading liver specialist, Professor Dame Sheila Sherlock, at the Royal Free Hospital in Hampstead. . . . When a biopsy was performed on his liver, it was found to be enormously enlarged and tumourous."

Though I can quote this passage from Roger Berthoud's biography of Graham Sutherland with impunity, I am apparently transgressing the GMC code on confidentiality if I detail Churchill's illnesses as revealed by Moran (and in this respect Leslie Witts's book review in the $B M F$ would also have offended had the provision then been in existence). And how about my repeating Geoffrey Keynes's account in The Gates of Memory of pumping out Virginia Woolf's stomach at her suicide attempt in 1914, for this is surely "confidential information which the late Sir G L Keynes obtained in the course of a professional relationship with the late Mrs A V Woolf ?" Similarly it must be unethical for a doctor to quote in public Lord Horder's medical report on Wingate to the Director General of Medical Services (which is printed in full in Christopher Sykes's biography) because it is taken from the papers of Dr Ben Kounine, Wingate's GP.

\section{Attitudes to confidentiality}

My first point is, then, that our attitudes to confidentiality should be re-examined and that doctors should not contravene 
any code in quoting published material. For the ordinary citizen confidentiality is an entitlement during life and for some time after death; for the national decision maker I doubt whether it can be. In their lifetimes the lay journalist has a legitimate interest in the health of the great (witness the current hullabaloo about Andropov); once they are dead the historian needs to be able to evaluate the possible influence of illness on important decisions. Just as politicians recognise that they can be talked and written about in terms that would entitle a layman to sue for libel, I believe that they would accept that their health is a public concern. As a historian, Malcolm Elwin, pointed out in The Times correspondence about Lord Moran:

"If Sir Winston Churchill had felt impelled by his infirmities to withdraw from public into private life, then an intrusion might have been justly resented by his family representatives. But rightly or wrongly Sir Winston in 1951 elected to continue in public life and therefore all personal information about him is legitimate and possibly essential material for the historian and biographer."

Perhaps Lord Moran should have waited 30 years to release the medical information, the delay laid down for most government documents, and it may be that good taste would suggest that the facts should have been made available to scholars as documents (as occurred last week) rather than published as a book. On the other hand, the historian Denis Brogan (who, like Leslie Witts in his $B M F$ review, was in no doubt about the value of Moran's book for scholars) thought that there was some advantage in publishing such records while some of the people were still alive and could answer the points raised-and the recent Reith lecturer, Sir Douglas Wass, has argued for a shorter period than the 30 year limit.

All this, of course, is not necessarily to say that doctors should aid and abet historians, but there is a cogent case for ensuring that the facts are right. Thus, secondly, I believe that doctors should be allowed to give details in public about the illness of a dead person where this will serve to correct a serious error and rehabilitate an individual's reputation. Wingate's attempted suicide is one such example; another is Lord Northcliffe's alleged neurosyphilis-which was shown in a letter to The Times by a former house physician of Lord Horder to have really been subacute bacterial endocarditis.

\section{Effect on historians}

Thirdly, the GMC needs to examine the effects of its code on the historian. At present the code is founded on statute law rather than case law and inevitably absurdities will result. It puts the historian with a medical qualification at a disadvantage compared with his lay colleagues; in particular, it does not specify any time limit for disclosure-is one behaving unethically, for instance, in repeating the observations of George III's physicians, or those of Chekhov, Somerset Maugham, or Freud on identifiable patients?

To take another example of my own, in the Christmas issue of the BMF I published an account of Yeats's Steinach operation which included extracts from some letters by Oliver St John Gogarty. Gogarty was a lifelong friend and fellow poet of W B Yeats; he was also on occasion his medical adviser. How can a biographer with the disadvantage of a medical qualification distinguish which facts have been disclosed under medical confidentiality and which in the course of ordinary conversation-and, given that the whole of literary Dublin in the 1930s was buzzing with accounts of Yeats's Steinach operation, is this not taking confidentiality to absurd limits ?

These difficulties, and others, are expounded in the article by Dr Loudon below (which I have placed in a separate appendix lest he should not agree with all the points I make here).

Fourthly, medical editors are sometimes placed in difficulties over accounts in obituaries. Usually these cloak the details of a person's final illness in conventional phrases, but sometimes they give full clinical descriptions; given that such accounts may be written by the person's own doctor or colleagues, does this contravene the code of confidentiality, even though the relatives are happy for the details to be given?

As an example, a few weeks ago the $B M \mathcal{F}$ was asked by two doctors to publish an obituary tribute to Professor Dorothy Russell; this stated that she wished it to be known that until middle age she had suffered from epilepsy, as this fact would encourage those with the same condition. Knowing that the writers were eminent in their specialty, and that this was just the sort of attitude Dorothy Russell would have taken, we had no hesitation in printing the tribute-but again this decision could be challenged on a strict interpretation of the code of confidentiality.

Finally, it needs to be pointed out that people other than doctors have had agonising decisions to take about making personal facts public. Such a problem was faced by Nigel Nicolson in deciding whether to publish the moving and revealing account by his mother, Vita Sackville-West, of her lesbian relationship with Violet Trefusis. "I do not believe," Nicolson wrote in his introduction to Portrait of a Marriage, "that she would deplore the revelation of her secret, knowing that it could help and encourage those similarly placed today"adding "let not the reader condemn in ten minutes what I have pondered for ten years."

Clearly decisions of these kinds must depend on the motive behind publication rather than the mere facts as stated. Every case must be judged on its merits, and there is an urgent need to reconsider the whole issue. In my view the GMC should consider doing this.

\section{How it strikes a historian}

\section{IRVINE LOUDON}

In the nineteenth century it was certainly common for medical men to write, and editors of medical periodicals to publish, clinical details in obituary notices. Before 1850 clinical reports on the last illness of medical men and postmortem reports were very often included in published obituaries, and someone who has examined thousands of such obituaries assures me that no one ever complained nor was there ever evidence of permission being sought prior to publication. No one today would want to return to such practices, and I am not sure whether our present strict attitudes on medical confidentiality evolved slowly or by sudden steps through cases such as Moran and Churchill. But if one reads the recent (August 1983) publication by the GMC, Professional Conduct and Discipline: Fitness to Practice (particularly p 19 lines 3-5, and p 20-21 para 6), in conjunction with the report in the $B M \mathcal{F}$ on professional conduct (12 November, p 1488) it seems that the position of the medically qualified historian, among others, is far from clear.

For two reasons I have recently become aware in a wider context that codes concerning medical confidentiality are often much less clear than is generally supposed, to the confusion of those who try to impose rules strictly.

Firstly, much of my time is now spent in research based on medical records in county record offices throughout England. Through this I have found that the time limit imposed by county archivists varies

Wellcome Unit for the History of Medicine, Oxford OX2 6PE

IRVINE LOUDON, DM, FRCGP, Wellcome research fellow in the University of Oxford 